$\begin{array}{cc}\text { ACADEMIA ROMÂNĂ } & \text { Rev. Roum. Chim., } \\ \text { 2019, 64(10), 859-866 } & \text { Devi: 10.33224/rrch.2019.64.10.04 } \\ \text { Rttp://web.icf.ro/rrch/ } & \end{array}$

\title{
DEVELOPMENT OF REVERSE PHASE LIQUID CHROMATOGRAPHIC METHOD BY USING CORE SHELL PARTICLES COLUMN FOR DETERMINATION OF MONTELUKAST AND LEVOCETIRIZINE FROM PHARMACEUTICAL CAPSULE DOSAGE FORMS
}

\author{
Cem ERKMEN, Selda ZENGINN KURNALI and Bengi USLU* \\ Ankara University, Faculty of Pharmacy, Department of Analytical Chemistry, 06560, Ankara, Turkey
}

Received November 20, 2018

\begin{abstract}
The aim of this paper is to develop a reverse phase high performance liquid chromatographic method with UV detection using the new generation core-shell columns to analyze montelukast and levocetirizine. For this aim, the mobile phase compositions, buffer solutions at different concentrations, $\mathrm{pH}$, flow rate and temperature effects are optimized for the separation of drug compounds. The chromatographic separation was achieved on Kinetex ${ }^{\circledR}$ C $18(150 \mathrm{~mm} \times 4.6 \mathrm{~mm}, 5 \mu \mathrm{m})$ as stationary phase. Mobile phase consist of methanol:10 mM ammonium acetate buffer $(85: 15, \mathrm{v} / \mathrm{v}) \mathrm{pH} 4.0$ at a flow rate of $1.5 \mathrm{~mL} \mathrm{~min}^{-1}$, column temperature of $40{ }^{\circ} \mathrm{C}$ and UV detection at $240 \mathrm{~nm}$. The proposed this method was used successfully for simultaneous determination of montelukast and levocetirizine in capsule dosage forms.
\end{abstract}

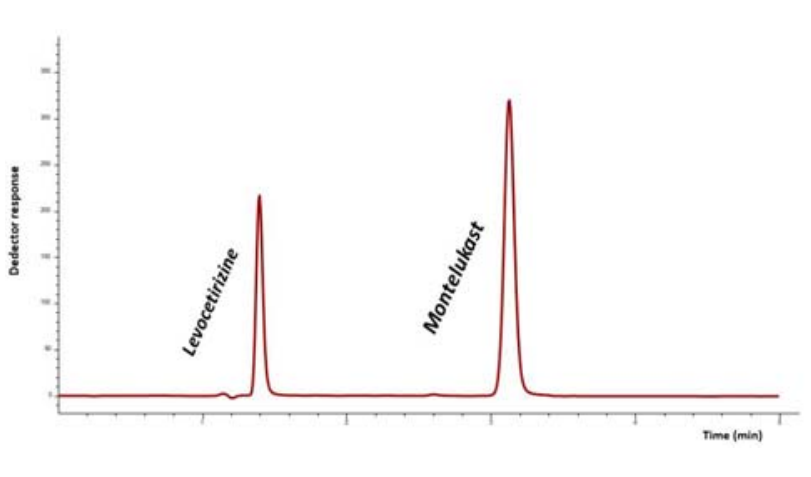

\section{INTRODUCTION}

Rhinitis is an inflammation of the nose's mucous lining. Some symptoms such as sneezing, rhinorrhea, itching, nasal obstruction and post nasal drip are seen in Rhinitis. While asthma has been known as symptoms of lower respiratory tract diseases, allergic rhinitis has been known as symptoms of upper respiratory tract diseases. Airway hypersensitivity, early phase allergic reactions and late phase allergic reactions, can be seen in both the lungs and nose simultaneously. ${ }^{1}$ Montelukast sodium (MON) is a potent active and specific leukotriene receptor antagonist. Also, it was approved for the treatment of seasonal allergic rhinitis and asthma's symptoms by the US Food and Drug Administration (FDA). ${ }^{2-4}$ It's chemical name is 2-[1-[1(R)-[3-[2(E)-(7-chloroquinolin-2yl)vinyl] phenyl]- 3[2-(1-hydroxy-1-methylethyl)phenyl]propylsulfanylmethyl] cyclopropyl] acetic acid sodium salt (Fig. 1). ${ }^{5}$ Levocetirizine (LEV) is a second generation antihistamine. It was approved by the FDA for the treatment of perennial allergic rhinitis and seasonal allergic rhinitis' symptoms. ${ }^{6}$ It's chemical name is (I), 2-[2-[4-[(R)-(4-chlorophenyl)-phenyl-methyl] piperazinyl-1-yl]ethoxy] acetic acid and it is the R-enantiomer of racemic cetirizine. ${ }^{7}$ Theoretically, combination of LEV and MON may enhance treating nasal symptoms' therapeutic effectiveness. There are different pharmaceutical dosage forms combination of LEV and MON that effect inhibition of both early phase and late phase reactions in allergic rhinitis. ${ }^{1}$

\footnotetext{
*Corresponding author: buslu@pharmacy.ankara.edu.tr
} 
$\mathbf{A}$<smiles>CC(C)(O)c1ccccc1CCC(SCC1(CC(=O)O)CC1)c1cccc(/C=C/c2ccc3ccc(Cl)cc3n2)c1</smiles>

B<smiles>O=C(O)COCCN1CCN(C(c2ccccc2)c2ccc(Cl)cc2)CC1</smiles>

Fig. 1 - Chemical structure of MON (A) and LEV (B).

High performance liquid chromatography (HPLC) has been most commonly used as a main analysis technique for analysis, research, identification, diagnosis or manufacturing among different types of chromatography. There are some challenges in HPLC. Highly efficient and the best separation which has high resolution and relatively low back pressure are primary issues for different types of samples such as food, pharmaceuticals, metabolomics, pesticides, etc. In recent years, a new generation column which has core shell silica particles have been increasingly used to obtain highly efficient separation which has both relatively low back pressure and fast flow rate. ${ }^{8}$

Different analysis methods for the determination of montelukast, ${ }^{5,9-15}$ and for the determination of levocetirizine ${ }^{9,13-16}$ have been reported in the literature. The aim of this paper is to optimize and develop a reversed phase high performance liquid chromatography method using the core shell columns for simultaneously MON and LEV capsule form that is pharmaceutical dosage forms.

\section{EXPERIMENTAL}

\section{Materials and Methods}

\subsection{Instruments}

The used reversed phase liquid chromatography system:

- The Agilent 1100 HPLC system (Wilmington, DE, USA) consist of G1313A ALS autosampler, G1311A quaternary pump, G1316A temperature controller, and 1315B DAD variable wavelength detector.

- Software: Chemstation

Human Corp. Zeneer Power I system (Human Corporation, Seoul, Korea) was used in order to obtain chromatographic grade water. All necessary solutions were prepared by using this water.

The $\mathrm{pH}$ of all the buffer solutions were measured out by using Mettler Toledo MA 235 pH, Hanna HI 1332 pH meter (Mettler Toledo TR, Turkey).

\subsection{Materials}

MON and LEV were kindly purchased from SigmaAldrich (St. Louis, MO, USA). While all chemicals which were used in experiments were analytical grade, all solvents which were used in experiments were chromatographic grade. Methanol and acetonitrile were commercially available from Sigma-Aldrich (St. Louis, MO, USA). Sodium hydroxide, hydrochloric acid, ortophosphoric acid and hydrogen peroxide were purchased from Merck (Darmstadt, Germany). Analytical column which was used in experiments, Kinetex ${ }^{\circledR}$ C $18(150 \mathrm{~mm} \times 4.6 \mathrm{~mm}, 5 \mu \mathrm{m}$ particle size $)$ was purchased from Phenomenex Inc. (Torrance, CA, USA).

\section{Preparation of Solutions}

\subsection{Preparation of Stock Solutions and Calibration Solutions}

Stock solutions of $100 \mu \mathrm{g} \mathrm{mL} L^{-1} \mathrm{MON}$ and $100 \mu \mathrm{g} \mathrm{mL}^{-1}$ LEV were prepared in acetonitrile. These solutions were kept in refrigerator at $+4{ }^{\circ} \mathrm{C}$. To prepare working solutions, stock solutions were diluted by using the mobile phase. For calibration studies, the concentration of MON and LEV were adjusted between 0.5 and $100.0 \mu \mathrm{g} \mathrm{mL}^{-1}$. In this method, graph of calibration was obtained by plotting the peak area of the compounds against the concentration of compounds using five replicated analyses.

\subsection{Preparation of Pharmaceutical Dosage Form}

Five Bronchorest ${ }^{\circledR} 10 \mathrm{mg} / 5 \mathrm{mg}$ capsules, which were claimed to contain $10 \mathrm{mg} \mathrm{MON}$ and $5 \mathrm{mg} \mathrm{LEV}$, were weighed and then were crushed to obtain a homogeneous powder. This powder's accurate weight equivalent to one capsule content was weighed. Then, it was diluted with acetonitrile in a $50 \mathrm{~mL}$ flask. After this solution kept in an ultrasonicator for $10 \mathrm{~min}$, the volume completed with acetonitrile. For the filtration, 0.45 $\mu \mathrm{m}$ membrane syringe filter was used. The filtered $200 \mu \mathrm{g} \mathrm{mL}$ ${ }^{1}$ stock solution was prepared in a calibrated $50 \mathrm{~mL}$ flask. In order to obtain a final solution, these solutions were diluted with mobile phase.

\section{Optimization of Method}

In order to determine the most suitable chromatographic conditions for the analysis of MON and LEV, firstly, the stationary phase properties such as functional group, particle diameter and silica type were evaluated. Then, ratio of the mobile phase composition, the effect of the mobile phase's organic solvent type, the flow rate and the temperature were investigated. As a result of these investigations, the most 
suitable stationary phase was selected and chromatographic analyses were performed by taking the system suitability test (SST) parameters into consideration.

\subsection{Effect of Mobile Phase Composition}

Methanol $(\mathrm{MeOH})$ ratio in mobile phase was changed to 90 , 85 and $80 \%$ by volume to determine for the best separation by using Kinetex C18 (150 mm x $4.6 \mathrm{~mm}, 5.0 \mu \mathrm{m})$ column keeping other conditions as $10 \mathrm{mM}$ (pH:4.0) ammonium acetate buffer solution at $25^{\circ} \mathrm{C}$ and flow rate of $1 \mathrm{~mL} \mathrm{~min}^{-1}$.

\subsection{Effect of Flow Rate}

Kinetex C18 (150 mm x $4.6 \mathrm{~mm}, 5.0 \mu \mathrm{m})$ column, $25^{\circ} \mathrm{C}$, $\mathrm{MeOH}$ : ammonium acetate buffer solution $-10 \mathrm{mM}(\mathrm{pH}: 4.0)$ $(80: 20 ; \mathrm{v} / \mathrm{v})$ were kept fixed and considering the column pressure, the flow rate was tested between 1.0 and $1.5 \mathrm{~mL} \mathrm{~min}^{-1}$.

\subsection{Effect of Buffer Solution's Type}

Kinetex C18 (150 mm x $4.6 \mathrm{~mm}, 5.0 \mu \mathrm{m})$ column, $25^{\circ} \mathrm{C}$, $240 \mathrm{~nm}, \mathrm{MeOH}:$ Buffer solution -10 mM (pH:4.0) (85:15; v/v) were kept fixed. Since the buffer solutions will be different interaction with the compounds to be analyzed depending on the ambient conditions, in this study ammonium acetate and ammonium formate buffer solutions were determined.

\subsection{Effect of Organic Solvent's Type}

As a result of the analyses, organic solvents that are wasted have hazardous effects to environment as well as it increase the cost. For this study, all chromatographic conditions were kept fixed and the effect of organic solvent which has different polarities on the analyses was evaluated. For this reasons, methanol and acetonitrile were used for this experiment.

\subsection{Effect of Temperature}

One of the most effective parameters used in optimization studies is the temperature. In the reverse phase liquid chromatography method which have chosen in the optimization studies, when temperature is increased, analysis time is shorten with smooth peak shapes. The temperature was changed from $20{ }^{\circ} \mathrm{C}$ to $40{ }^{\circ} \mathrm{C}$ for the best and fast separation results.

\subsection{Effect of Buffer Solution's Molarity}

Buffer solution's molarity is the most effective parameters used in optimization. Increased salt concentration with mobile phase composition leads to blockages in the column and a decrease in column life. The buffer solution's molarity was changed from $5 \mathrm{mM}$ to $40 \mathrm{mM}$ to obtain best separation results.

\section{Validation Procedure}

The validation procedure was carried out according to the ICH guidelines. The developed method was validated for quantitation of the binary mixture of MON and LEV from their raw formulation and marketed preparations from the view point of system suitability, linearity range, specificity, accuracy and precision, etc.

\section{RESULTS AND DISCUSSION}

The first step for the validation of an analytical method is to determine the optimum conditions for this method. Since HPLC method was used in this study, the effects of different factors such as mobile phase composition, temperature and organic solvent were investigated.

Firstly, the mobile phase composition was studied. Methanol and buffer solution mixtures were injected into the system at different ratios (v/v) which include $90 \%, 85 \%$ and $80 \%$ methanol. The system suitability test results were illustrated in Table 1. According to the results, as we work with reverse phase technique, the retention time increases as the percentage of methanol decreases. Selectivity, number of theoretical plates and resolution results indicate that all three ratios can be used for analysis.

The increased flow rate in chromatographic studies increases the column pressure while shortening the analysis time. This situation may also cause excessive pressure to damage the stationary phase. Three different flow rate experiments were conducted and the results are shown in Table 2. Also, these results indicate that all flow rates can be used for analysis.

\section{Table 1}

System suitability test parameters results according to mobile phase composition by using Kinetex C 18 (150 mm x $4.6 \mathrm{~mm}, 5.0 \mu \mathrm{m})$ column, $25^{\circ} \mathrm{C}, 1 \mathrm{~mL} \mathrm{~min}^{-1}$ flow rate, $240 \mathrm{~nm}, \mathrm{pH}: 4.010 \mathrm{mM}$ ammonium acetate buffer solution $\left(\mathrm{t}_{\mathrm{r}}\right.$ : Retention time, $\mathrm{N}$ : Theoretical plates, $\mathrm{R}_{\mathrm{s}}$ : Resolution, $\alpha$ : Selectivity)

\begin{tabular}{c|ccccccccc}
\hline Mobile Phase Composition & \multicolumn{4}{|c}{ LEV } & \multicolumn{7}{c}{ MON } \\
\cline { 2 - 10 } & $\mathbf{t}_{\mathbf{r}}(\mathbf{m i n})$ & $\mathbf{N}$ & $\mathbf{R}_{\mathbf{s}}$ & $\boldsymbol{\alpha}$ & $\mathbf{t}_{\mathbf{r}}(\mathbf{m i n})$ & $\mathbf{N}$ & $\mathbf{R}_{\mathbf{s}}$ & $\boldsymbol{\alpha}$ \\
& & & & & & & & & \\
\hline MeOH: Buffer (90:10) & 1.58 & 4692 & - & - & 2.63 & 8264 & 10.04 & 4.75 \\
\hline MeOH: Buffer (85:15) & 1.69 & 4890 & - & - & 4.24 & 10020 & 19.09 & 14.42 \\
\hline MeOH: Buffer (80:20) & 1.87 & 5070 & - & - & 8.57 & 11340 & 31.32 & 21.94 \\
\hline
\end{tabular}


Table 2

System suitability test parameters results according to flow rate by using Kinetex C $18(150 \mathrm{~mm}$ x $4.6 \mathrm{~mm}, 5.0 \mu \mathrm{m})$ column, $25^{\circ} \mathrm{C}, 240 \mathrm{~nm}, \mathrm{MeOH}: B u f f e r$ solution $10 \mathrm{mM}(\mathrm{pH}: 4.0)(80: 20 ; \mathrm{v} / \mathrm{v})\left(\mathrm{t}_{\mathrm{r}}\right.$ : Retention time, $\mathrm{N}$ : Theoretical plates, $\mathrm{R}_{\mathrm{s}}$ : Resolution, $\alpha$ : Selectivity)

\begin{tabular}{|c|c|c|c|c|c|c|c|c|}
\hline \multirow[t]{2}{*}{ Flow Rate } & \multicolumn{4}{|c|}{ LEV } & \multicolumn{4}{|c|}{ MON } \\
\hline & $t_{r}(\min )$ & $\mathbf{N}$ & $\mathbf{R}_{\mathrm{s}}$ & $\alpha$ & $t_{r}(\min )$ & $\mathbf{N}$ & $\mathbf{R}_{\mathrm{s}}$ & $\alpha$ \\
\hline $1.00 \mathrm{ml} \mathrm{min}^{-1}$ & 1.87 & 5070 & - & - & 8.57 & 11340 & 31.32 & 21.94 \\
\hline $1.25 \mathrm{ml} \mathrm{min}^{-1}$ & 1.50 & 3849 & - & - & 6.80 & 10060 & 28.73 & 21.38 \\
\hline $1.50 \mathrm{ml} \mathrm{min}^{-1}$ & 1.27 & 3149 & - & - & 5.69 & 8213 & 25.88 & 20.97 \\
\hline
\end{tabular}

Table 3

System suitability test parameters results according to buffer solution's type by using Kinetex C18 $(150 \mathrm{~mm} \times 4.6 \mathrm{~mm}, 5.0 \mu \mathrm{m})$ column, $25^{\circ} \mathrm{C}, 240 \mathrm{~nm}$, MeOH:Buffer solution $-10 \mathrm{mM}$ $(\mathrm{pH}: 4.0)(85: 15 ; \mathrm{v} / \mathrm{v})\left(\mathrm{t}_{\mathrm{r}}\right.$ : Retention time, $\mathrm{N}$ : Theoretical plates, $\mathrm{R}_{\mathrm{s}}$ : Resolution, $\alpha$ : Selectivity)

\begin{tabular}{c|ccccccccc}
\hline Type of Buffer Solution & \multicolumn{4}{|c}{ LEV } & \multicolumn{1}{c}{ MON } \\
\cline { 2 - 10 } & $\mathbf{t}_{\mathbf{r}}(\mathbf{m i n})$ & $\mathbf{N}$ & $\mathbf{R}_{\mathbf{s}}$ & $\boldsymbol{\alpha}$ & $\mathbf{t}_{\mathbf{r}}(\mathbf{m i n})$ & $\mathbf{N}$ & $\mathbf{R}_{\mathbf{s}}$ & $\boldsymbol{\alpha}$ \\
\hline Ammonium acetate & 1.69 & 4890 & - & - & 4.24 & 10020 & 19.09 & 14.42 \\
\hline Ammonium formate & 1.70 & 5039 & - & - & 4.63 & 10535 & 21.17 & 15.69 \\
\hline
\end{tabular}

\section{Table 4}

System suitability test parameters results according to organic solvents type by using Kinetex C $18(150 \mathrm{~mm}$ x $4.6 \mathrm{~mm}, 5.0 \mu \mathrm{m})$ column, $25^{\circ} \mathrm{C}, 240 \mathrm{~nm}$, Organic Solvent:Buffer Solution-10 mM (pH:4.0) (85:15; v/v) ( $\mathrm{t}_{\mathrm{r}}$ : Retention time, N: Theoretical plates, $\mathrm{R}_{\mathrm{s}}$ : Resolution, $\alpha$ : Selectivity)

\begin{tabular}{c|ccccccccc}
\hline Organic Solvent & \multicolumn{4}{|c}{ Lev } & \multicolumn{1}{c}{ Mon } \\
\cline { 2 - 9 } & $\mathbf{t}_{\mathbf{r}}(\mathbf{m i n})$ & $\mathbf{N}$ & $\mathbf{R}_{\mathbf{s}}$ & $\boldsymbol{\alpha}$ & $\mathbf{t}_{\mathbf{r}}(\mathbf{m i n})$ & $\mathbf{N}$ & $\mathbf{R}_{\mathbf{s}}$ & $\boldsymbol{\alpha}$ \\
\hline Methanol & 1.69 & 4890 & - & - & 4.24 & 10020 & 19.09 & 14.42 \\
\hline Acetonitrile & 1.61 & 4088 & - & - & 2.79 & 10344 & 11.23 & 4.05 \\
\hline
\end{tabular}

\section{Table 5}

System suitability test parameters results according temperature by using Kinetex C 18 $(150 \mathrm{~mm} \times 4.6 \mathrm{~mm}, 5.0 \mu \mathrm{m})$ column, flow rate: $1 \mathrm{ml} \mathrm{min}^{-1}, 240 \mathrm{~nm}, \mathrm{MeOH}: B u f f e r$ solution $-10 \mathrm{mM}(\mathrm{pH}: 4.0)(85: 15 ; \mathrm{v} / \mathrm{v})\left(\mathrm{t}_{\mathrm{r}}\right.$ : Retention time, $\mathrm{N}$ : Theoretical plates, $\mathrm{R}_{\mathrm{s}}$ : Resolution, $\alpha$ : Selectivity)

\begin{tabular}{c|cccccccc}
\hline \multirow{2}{*}{ Temperature } & \multicolumn{5}{|c}{ LEV } & \multicolumn{7}{c}{ MON } \\
\cline { 2 - 9 } & $\mathbf{t}_{\mathbf{r}}$ (min) & $\mathbf{N}$ & $\mathbf{R}_{\mathbf{s}}$ & $\boldsymbol{\alpha}$ & $\mathbf{t}_{\mathbf{r}}$ (min) & $\mathbf{N}$ & $\mathbf{R}_{\mathbf{s}}$ & $\boldsymbol{\alpha}$ \\
\hline $\mathbf{2 0}{ }^{\mathbf{0}} \mathbf{C}$ & 1.76 & 5005 & - & - & 4.90 & 10119 & 21.21 & 13.62 \\
\hline $\mathbf{2 5}^{\mathbf{0}} \mathbf{C}$ & 1.74 & 4898 & - & - & 4.63 & 9927 & 20.08 & 14.75 \\
\hline $\mathbf{3 0}^{\mathbf{0}} \mathbf{C}$ & 1.72 & 4936 & - & - & 4.35 & 10207 & 19.41 & 11.73 \\
\hline $\mathbf{4 0}^{\mathbf{0}} \mathbf{C}$ & 1.68 & 4962 & - & - & 3.84 & 10577 & 17.37 & 11.50 \\
\hline
\end{tabular}




\section{Table 6}

System suitability test parameters results according to the buffer solution's molarity by using Kinetex C18 (150 mm x $4.6 \mathrm{~mm}, 5.0 \mu \mathrm{m})$ column, flow rate: $1 \mathrm{ml} \mathrm{min}^{-1}, 240 \mathrm{~nm}$, MeOH:Buffer solution (pH:4.0) $(85: 15 ; \mathrm{v} / \mathrm{v})\left(\mathrm{t}_{\mathrm{r}}\right.$ : Retention time, $\mathrm{N}$ : Theoretical plates, $\mathrm{R}_{\mathrm{s}}$ : Resolution, $\alpha$ : Selectivity)

\begin{tabular}{c|cccccccc}
\hline Buffer Solution Molarity & \multicolumn{4}{|c}{ LEV } & \multicolumn{5}{c}{ MON } \\
\cline { 2 - 9 } & $\mathbf{t}_{\mathbf{r}}$ (min) & $\mathbf{N}$ & $\mathbf{R}_{\mathbf{s}}$ & $\boldsymbol{\alpha}$ & $\mathbf{t}_{\mathbf{r}}$ (min) & $\mathbf{N}$ & $\mathbf{R}_{\mathbf{s}}$ & $\boldsymbol{\alpha}$ \\
\hline $\mathbf{5} \mathbf{~ m M}$ & 1.74 & 5013 & - & - & 4.50 & 10375 & 19.97 & 13.11 \\
\hline $\mathbf{1 0} \mathbf{~ m M}$ & 1.74 & 4898 & - & - & 4.63 & 9927 & 20.08 & 14.75 \\
\hline $\mathbf{2 0} \mathbf{~ m M}$ & 1.74 & 5010 & - & - & 4.61 & 10618 & 20.54 & 16.33 \\
\hline $\mathbf{4 0} \mathbf{~ m M}$ & 1.73 & 4960 & - & - & 4.45 & 10162 & 19.59 & 13.45 \\
\hline
\end{tabular}

Table 7

Optimum conditions for recommended method

\begin{tabular}{c|c}
\hline Instrument & Agilent $1100 \mathrm{HPLC}$ system \\
\hline Column & Kinetex C $18(150 \mathrm{~mm} \mathrm{x} 4.6 \mathrm{~mm}, 5.0 \mu \mathrm{m})$ \\
\hline Wavelength & $240 \mathrm{~nm}$ \\
\hline Temperature & $40^{\circ} \mathrm{C}$ \\
\hline Flow rate & $1.5 \mathrm{ml} \mathrm{min}^{-1}$ \\
\hline Injection volume & $10 \mu \mathrm{l}$ \\
\hline Mobil phase & Methanol: Ammonium acetate $(10 \mathrm{mM}, \mathrm{pH}: 4.0),(85: 15, \mathrm{v} / \mathrm{v})$ \\
\hline
\end{tabular}

Table 8

System suitability test parameters in optimized conditions

\begin{tabular}{|c|c|c|c|}
\hline Parameters & MON & LEV & According to ICH ${ }^{19}$ \\
\hline Retention time $\left(t_{r}\right)(\mathrm{min})$ & 1.35 & 3.09 & - \\
\hline Resolution $\left(\mathbf{R}_{\mathrm{s}}\right)$ & - & 16.07 & $>2.0$ \\
\hline $\begin{array}{l}\text { Theoretical plates(N) } \\
\text { (Plates/meter) }\end{array}$ & 3986 & 8992 & $>2000$ \\
\hline Selectivity ( $\alpha$ ) & - & 6.77 & $>1.0$ \\
\hline Tailing factor & 0.86 & 0.91 & $\leq 2.0$ \\
\hline
\end{tabular}

\section{Table 9}

Validation parameters in optimized conditions

\begin{tabular}{c|cc}
\hline Parameters & LEV & MON \\
\hline Linearity Range $\left(\boldsymbol{\mu g} \mathbf{~ m L}^{-\mathbf{1}}\right)$ & $0.5-100$ & $0.5-100$ \\
\hline Slope & 7.08 & 16.22 \\
\hline Correlation Coefficient & 0.999 & 0.999 \\
\hline Limit of Quantification $\left(\boldsymbol{\mu g} \mathbf{~ m L}^{-\mathbf{1}}\right)$ & 0.47 & 0.16 \\
\hline Limit of Detection $\left(\boldsymbol{\mu g} \mathbf{~ m L}^{-\mathbf{1}}\right)$ & 0.16 & 0.05 \\
\hline Within-day Precision* $\left.\mathbf{R S D}_{\mathbf{~}}\right)$ & 0.33 & 0.26 \\
\hline Between-day Precision* $(\mathbf{R S D} \%)$ & 1.02 & 0.39 \\
\hline
\end{tabular}

* Each value is the mean of five experiments 
Due to difference in buffer solutions compositions, interaction of buffer components with the compounds to be analyzed depending on the ambient conditions will be different. The buffer solutions prepared for the experiments were used at the $\mathrm{pH}$ of $10 \mathrm{mM}$. According to both the column's chemical properties and the chromatographic conditions, buffer solutions can act differently on the analysis. In this study ammonium acetate and ammonium formate buffer solutions were used and the system suitability test results were illustrated in Table 3. Even if the test results are appropriate, an undesired peak from the ammonium formate buffer solution is formed in the chromatographic separation. Since this peak does not belong to any impurities or degradation product, ammonium acetate buffer solution was found to be suitable for optimum conditions.

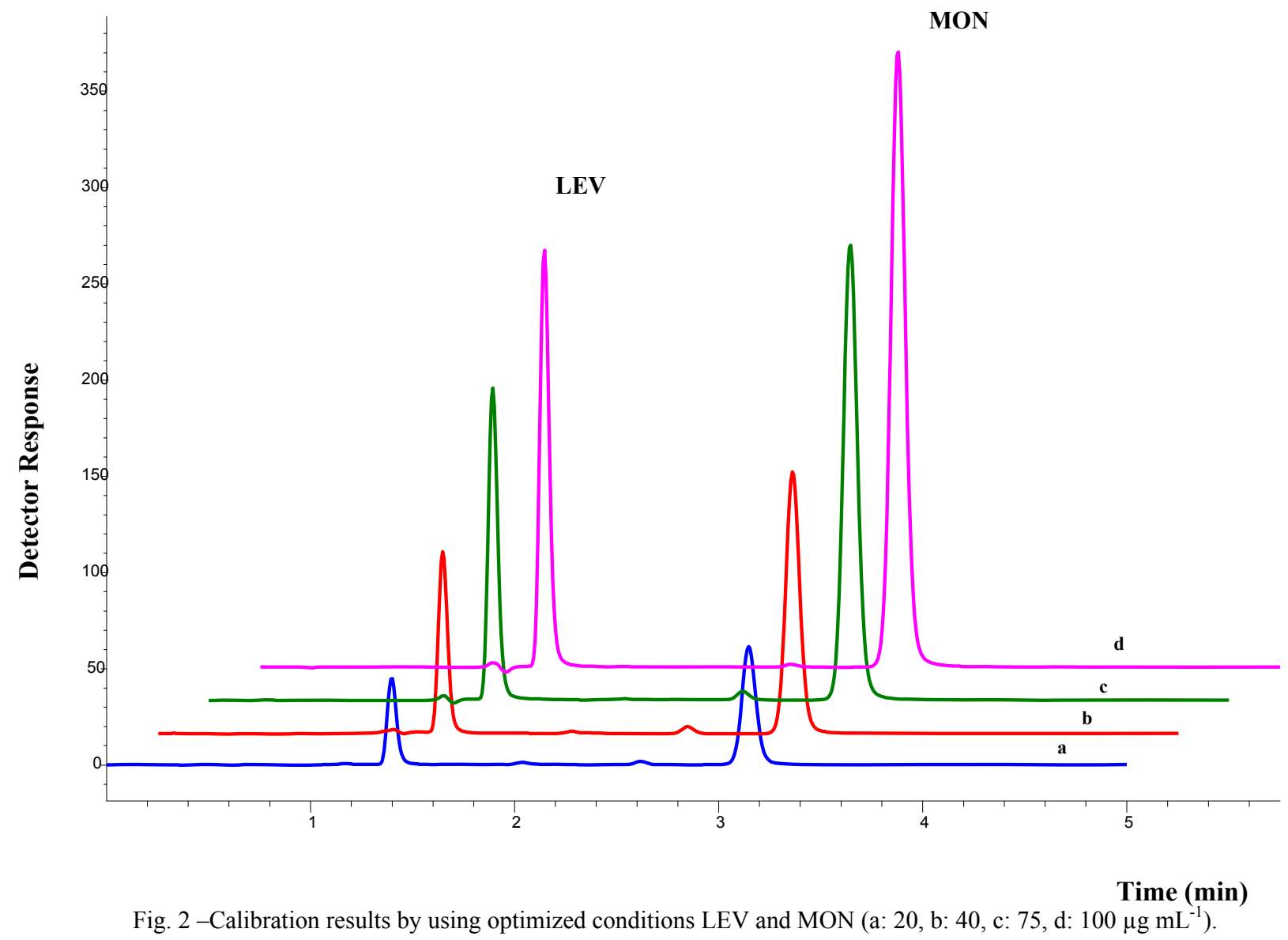

Table 10

The accuracy results of the simultaneous determination of LEV and MON in capsule dosage form

\begin{tabular}{|c|c|c|}
\hline Parameters & LEV & MON \\
\hline Labeled claim $\left(\mu \mathrm{g} \mathrm{mL}^{-1}\right)$ & 20.00 & 40.00 \\
\hline Amount found $\left(\mu \mathrm{g} \mathrm{mL}^{-1}\right)$ & 19.72 & 39.62 \\
\hline RSD (\%)* & 0.46 & 0.38 \\
\hline Bias (\%) & 4.02 & 0.84 \\
\hline Added $\left(\mu \mathrm{g} \mathrm{mL} L^{-1}\right)$ & 20.00 & 40.00 \\
\hline Found $\left(\mu \mathrm{g} \mathrm{mL} \mathrm{L}^{-1}\right)$ & 20.23 & 40.43 \\
\hline Recovery (\%) & 100.58 & 100.66 \\
\hline RSD of Recovery (\%) & 0.58 & 0.31 \\
\hline Bias of Recovery (\%) & -0.58 & -0.54 \\
\hline
\end{tabular}

*Each value is the mean of five experiments 


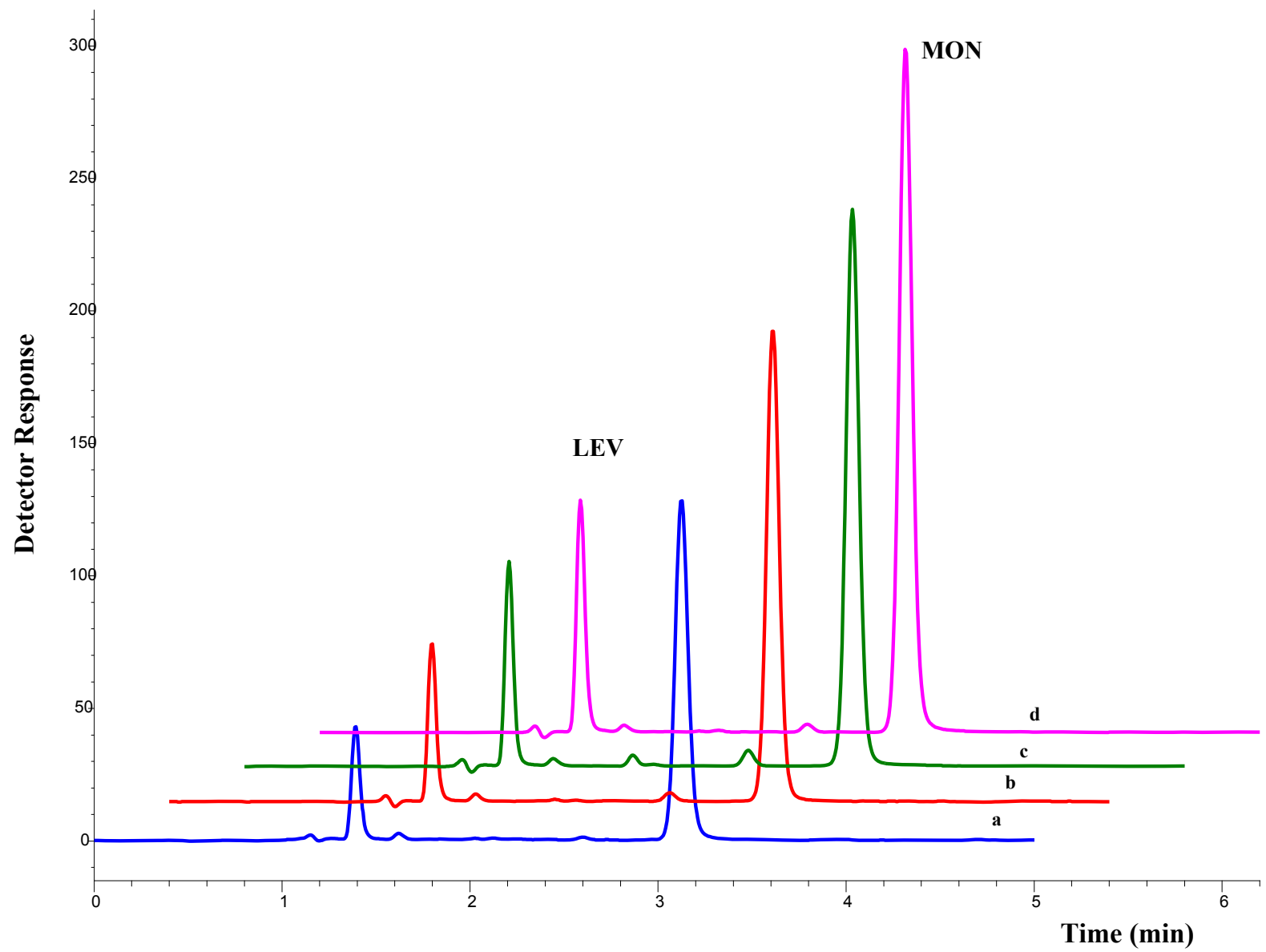

Fig. 3 - The capsule sample under optimized conditions (a), the addition of $25 \%$ active ingredient added into the tablet sample (b), the addition of $50 \%$ active ingredient added into the tablet sample (c), the addition of $100 \%$ active ingredient added into the tablet sample (d).

One of the main problem of HPLC methods is the production of high amount of hazardous organic wastes to the environment. Methanol and acetonitrile were used for this experiment and the system suitability test results were illustrated in Table 4. Although the use of acetonitrile shortens the analysis time, methanol was chosen for analysis because it is more environmentally friendly.

Temperature is one of the most important parameters affecting the chromatographic separation. Although it is possible for products to degrade with increasing column temperature, it is advantageous to shorten the analysis time. For this study the system suitability test results were illustrated in Table 5. Selectivity, number of theoretical plates and resolution results indicate that all four temperatures can be used for analysis. As the temperature increased, the drug compounds did not appear to be distorted therefore, the column temperature was chosen $40{ }^{\circ} \mathrm{C}$.

In the final stage of optimization, the buffer solution molarity was examined. The buffer solution molarity did not affect the test results in Table 6. Low concentrations have been preferred to prevent column clogging.
After the experimental processing is completed, identified optimum conditions are shown in the Table 7. System suitability was confirmed by using the 5 repeated injections of standard solution of mixture of MON and LEV. RSD \% of retention time, resolution, theoretical plate number, selectivity and tailing factor were also evaluated and determined. The system suitability test results were demonstrated in Table 8 . System suitability test parameters' results demonstrated that the developed method was appropriate for both validating and simultaneous determination of mixture of MON and LEV. When we compare our results with limit values in Table 8 , it can be said that the analysis results are appropriate because the number of theoretical plates is higher than 2000 for both compounds and the resolution is larger than 2 .

Reverse phase HPLC method was validated for MON and LEV. These validated parameters are linearity, specificity, accuracy, precision, limit of detection (LOD) and limit of quantification (LOQ). The validation results are shown in Table 9. According to the results, developed method is specific for MON and LEV which were separated from each other. Also, there is no interfering peak 
at the retention time of the MON and LEV peaks signals in Fig. 2. Linearity achieved over the range of concentrations between 0.5 and $100 \mu \mathrm{g} \mathrm{mL}^{-1}$. The linear regression of the data used the calibration curve demonstrated good relationship on the mentioned range of concentrations. Good correlation and the determination coefficient calculated as $\mathrm{R}^{2}>0.999$ were obtained. The developed method is linear over the range of 0.5 $100 \mu \mathrm{g} \mathrm{mL}^{-1}$. LOD and LOQ values were calculated from the equations where the slope of the calibration curve and the standard deviation of response were used. LOD values were found $0.47 \mu \mathrm{g} \mathrm{mL}^{-1}$ and $0.16 \mu \mathrm{g} \mathrm{mL}^{-1}$ for LEV and MON respectively. When LOD and LOQ values are examined, it is possible to analyze at microgram level for both compounds. Precision was determined according to measurement of experiments of standard solution both intraday and inter-day. The method's repeatability is determined based on the low values of RSD \% for method precision.

Accuracy of the developed method was determined by analyzing of MON and LEV (Fig. 3). Therefore, the equations from the calibration curves were used for the determination of MON and LEV in pharmaceutical dosage form. The recovery experiments were achieved by adding the known amount of standard solutions in the range between $25 \%$ to $100 \%$ over dosage form's solution. These experiments were repeated 5 times. The results of recovery such as RSD \% and Bias \% were shown in the Table 10. Mean of the spike recoveries was found nearly $100 \%$ at different levels which indicate an acceptable accuracy of the method. As a result, the developed method was not affected from the possible interferences in the dosage form.

\section{CONCLUSION}

In this work HPLC technique applied for the determination of LEV and MON capsules form, which are pharmaceutical dosage forms. The validation results show determination coefficients $\left(r^{2}\right)$ higher than 0.99 with the linearity range of $0.5-100 \mu \mathrm{g} \mathrm{mL}^{-1}$ for each compound. The limit of quantification was $0.47 \mu \mathrm{g} \mathrm{mL}^{-1}$ and $0.16 \mu \mathrm{g} \mathrm{mL}^{-1}$ and limit of detection was $0.16 \mu \mathrm{g} \mathrm{mL}^{-1}$ and $0.05 \mu \mathrm{g} \mathrm{mL}^{-1}$ for LEV and MON, respectively. Recovery values were found $100.58 \%$ and $100.66 \%$ for LEV and MON respectively. The proposed method shows a sensitive, cost-effective to the quantification of binary mixtures in pharmaceutical dosage form. There is no need of sample pretreatment, evaporation or extraction steps prior to start analysis in this method. The effect of core shell particles was also investigated and the selected stationary phase reduced the analysis time with better peak shapes. The analysis was carried out in a shorter time compared to other methods in the literature ${ }^{5,16}$. Finally, the present HPLC study is a fully validated, rapid, simple, sufficiently precise and accurate method for the simultaneous determination of LEV and MON.

Acknowledgements. The authors would like to thank Ankara University Scientific Research Projects Commission for financial support (Project No: 17H0237010).

\section{REFERENCES}

1. M. Kim, S. Y. Lee, H. Park, H. J. Yoon, S. Kim, Y. J. Cho, K. Yoo, S. Lee, H. Kim, J. Park, H. Park, J. Chung, B. W. Choi, B. Lee, Y. Chang, E. Jo, S. Lee, Y. S. Cho, Y. Jee, J. Lee, J. Jung and C. Park, Clin. Ther., 2018, 40, Article No 7.

2. H. Ochiai, N. Uchiyama, T. Takano, K. Hara and T. Kamei, J. Chromatogr. B, 1998, 713, 409-414

3. R. Papp, P. Luk, W. M. Mullett and E. Kwong, $J$. Chromatogr. B, 2007, 858, 282-286.

4. I. Alsarra, M. Al-Omar, E.A. Gadkariem, F. Belal, Il Farmaco, 2005, 60, 563-567.

5. T. Radhakrishna, A. Narasaraju, M. Ramakrishna and A. Satyanarayana, J. Pharm. Biomed. Anal., 2003, 31, 359-368.

6. D. Singh-Franco, H. L. Ghin, G. I. Robles, N. Borja-Hart and A. Perez, Clin. Ther., 2009, 31, Article No 8.

7. M. R. Morita, D. Berton, R. Boldin, F. A. P. Barros, E. C. Meurer, A. R. Amarante, D. R. Campos, S. A. Calafatti, R. Pereira, E. Abib Jr. and J. Pedrazolli Jr., J. Chromatogr. B, 2008, 862, 132-139.

8. R. Hayes, A. Ahmed, T. Edge and H. Zhang, J. Chromatogr. A, 2014, 1357, 36-52.

9. T. Raja and A. L. Rao, Int. J. Res. Pharm. Chem., 2012, 2, 1057-1063.

10. C. J. Kitchen, A. Q. Wang, D. G. Musson, A. Y. Yang and A. L. Fisher, J. Pharm. Biomed. Anal., 2003, 31, 647-654.

11. H. Vekaria, V. Limbasiya and P. Patel, J. Pharm. Res., 2013, 6, 134-139.

12. G. Nirupa, S. A. Kumar and U. M. Tripathi, J. Chem., 2013, Article ID 402723.

13. A. Basu, K. Basak, M. Chakraborty and I. S. Rawat, Int. J. Pharmtech. Res., 2011, 3, 405-410.

14. S. Somkuwar and A. K. Pathak, Pharmacia, 2012, 1, 90-94.

15. A. S. Rathore, L. Sathiyanarayanan and K. R. Mahadik, K., R., Pharm. Anal. Acta., 2010, 1, 1-6.

16. H. Al Aani and I. Alashkar, Int. J. Pharm. Sci. Rev. Res. 2013, 23, 64-71.

17. M. Gumustas, B. Uslu, S.A. Ozkan and H.Y. Aboul-Enein, Chromatographia, 2014, 77, 1721-1726.

18. N. Bounoua, K. Sekkoum, M. Gumustas, N. Belboukhari and S. A. Ozkan, Chirality, 2018, 30, 807-8015.

19. International Conference on Harmonization (ICH) Q2 (R1), Validation of Analytical Procedures: Text and Methodology, 2005 November. 